${ }^{15}$ Mellbin T, Vuille JC. Weight gain in infancy and physical development

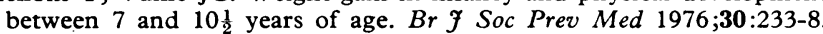

${ }^{16}$ Baird L, Silverstone JT, Grimshaw JJ, Ashwell M. Prevalence of obesity in a London borough. Practitioner 1974;212:706-14.

${ }^{17}$ Hammond WH. Measurement and interpretation of subcutaneous fat, with norms for children and young adult males. Br F Prev Soc Med 1955;9:201-11.

18 Whitelaw AGL. The association of social class and sibling number with skinfold thickness in London schoolboys. Hum Biol 1971;43:414-20.

19 Stunkard A, d'Aquili E, Fox S, Filion RDL. Influence of social class on obesity and thinness in children. $\mathcal{F} A M A 1972 ; 221: 579-84$
${ }^{20}$ Garn SM, Hopkins PJ, Ryan AS. Differential fatness gain of low income W0

boys and girls. Am $\mathcal{F}$ Clin Nutr $1981 ; 34: 1465-8$.
21 Cook J, Altman DG, Moore DMC, Topp SG, Holland NW, Elliot A. A survey of the nutritional status of schoolchildren. Relation between 2 nutrient intake and socio-economic factors. Br F Soc Prev Med 1973; C nutrient $27: 91-9$.

22 Durnin JVA, Lonergan ME, Good J, Ewan A. A cross-sectional nutritional and anthropometric study, with an interval of 7 years, on 611 young adolescent schoolchildren. Br F Nutr 1974;32:169-79.

(Accepted 20 fanuary 1983)

\title{
Role of carcinoembryonic antigen in detection of asymptomatic disseminated disease in colorectal carcinoma
}

\author{
I G FINLAY，C S MCARDLE
}

\begin{abstract}
Fifty one patients were studied prospectively to evaluate the role of sequential determinations of the carcinoembryonic antigen concentration in the detection of asymptomatic disseminated disease after curative resection for colorectal carcinoma. Computed tomography of the liver was performed during the immediate postoperative period in all patients. Serum concentrations of the antigen were estimated at three month intervals for a minimum of two years.

Computed tomography at the time of operation detected occult hepatic metastases in 12 patients. Of the remaining 39 patients, six developed local recurrence alone, two developed disseminated disease in the absence of hepatic metastases, and one developed hepatic disease at 10 months, as detected by sequential computed tomography. Of all 13 patients with asymptomatic hepatic metastases, only eight developed an increase in serum carcinoembryonic antigen concentrations before death. The median interval between detection by computed tomography and rise in antigen concentration was 7.5 months. The corresponding median interval from increase in concentration to death was only 5.5 months. Of the six patients who developed local recurrence alone, only two had raised concentrations of the antigen.

These results suggest that increase in the serum carcinoembryonic antigen concentration occurs late in colorectal carcinoma.
\end{abstract}

\section{Introduction}

The role of carcinoembryonic antigen as a marker in the management of colorectal carcinoma has recently been reviewed. ${ }^{1}$ It was concluded that sequential assay of plasma concentrations of the antigen was the best non-invasive technique available for the early detection of asymptomatic recurrence after apparently curative resection of colorectal carcinoma.

\footnotetext{
University Department of Surgery, Royal Infirmary, Glasgow G4 OSF

I G FINLAY, BSC, FRCS, senior registrar

C S MCARDLE, MD, FRCS, consultant surgeon

Correspondence to: Mr I G Finlay.
}

Those observations were based on studies in which increased concentrations of the antigen occurred before clinical detection
of recurrent disseminated disease. ${ }^{2-4}$

We reported that $29 \%$ of patients undergoing apparently 을 curative resection for colorectal carcinoma had occult hepatic $\vec{\circ}$ metastases which could be detected by computed tomography. ${ }^{5}$ क The presence of these metastases accounted for $88 \%$ of deaths within three years of surgery. ${ }^{6}$ The ability to detect occult disseminated disease at the time of laparotomy provides a unique $\vec{\varphi}$ opportunity to re-evaluate the role of sequential estimations of $\omega$ carcinoembryonic antigen in the detection of asymptomatic $D$ disseminated disease.

\section{Patients and methods}

We studied 51 consecutive patients surviving apparently curative $\frac{\overrightarrow{\bar{\sigma}}}{3}$ resection for colorectal carcinoma. Liver ultrasonography and computed tomography were performed during the immediate postoperative period in all patients. On the basis of these investigations patients were considered to have a disease free liver or to have occult hepatic metastases (hepatic metastases not detected by the surgeon). The accuracy of the initial hepatic scans was confirmed by progressive enlargement of lesions on sequential scans during follow up. This procedure has been fully described. ${ }^{5}$

All patients were reviewed one month after operation and at three month intervals thereafter for a minimum of 24 months (range 24-48 months) or until death. Blood was obtained for estimation of the 을 carcinoembryonic antigen value at each visit. These assays were per- $N$ formed by a double antibody radioimmunoassay on unextracted $\sigma$ serum. ${ }^{7}$ The upper limit of normal $(25 \mu \mathrm{g} / \mathrm{l})$ was based on a study of $\frac{D}{O}$ normal people previously undertaken at this hospital.

All patients underwent careful clinical and radiological follow up. No Sequential hepatic scanning was performed in those patients who had $N$ had an initial positive or equivocal scan. In addition, sequential hepatic $\sigma$ scanning, barium enema examination, and sigmoidoscopy were performed when clinically indicated and in all patients whose serum concentration of carcinoembryonic antigen began to rise. All surviving $\mathbb{D}$ patients underwent routine hepatic scanning two years after surgery.

Of the 51 patients studied, 39 were considered to have a disease free $T$ liver on the basis of hepatic scanning at the time of surgery. Thirty of these patients remained clinically and radiologically free of disease throughout the study. Six patients developed local recurrence alone, $\mathbb{D}$ one of whom died during follow up. Two patients developed disseminated disease in the absence of hepatic metastases. Both of these died during follow up and necropsy confirmed absence of disease in the $O$ liver. In one of the 39 patients considered to have a disease free liver at the time of surgery hepatic metastases were detected by sequential computed tomography at 10 months. This patient subsequently died 32 months after surgery. 
Occult hepatic metastases were detected at the time of surgery and subsequently confirmed during follow up in 12 patients. Of these, 10 died and two developed clinically evident hepatic disease.

\section{Results}

Of the 30 patients who remained free of disease, 26 had normal serum carcinoembryonic antigen concentrations throughout the follow up period. Three of the remaining four patients developed a transient rise in values. The fourth patient had a persistent modest rise in antigen concentration and remained clinically and radiologically free of disease at four years.

Only two of the six patients who developed local recurrence alone had an increase in the antigen concentration. In one of these the increase occurred before clinical and radiological detection of the recurrent disease.

The two patients found to have disseminated disease in the absence of hepatic metastases developed raised concentration of the antigen at the time of clinical detection of recurrent disease. They died two and three months respectively after the rise in values.

Of all 13 patients with hepatic metastases, only one had a raised carcinoembryonic antigen concentration at the time of surgery. A further seven patients developed raised values before death. In these patients the median interval between detection by computed tomography and the rise in antigen concentration was 7.5 months. These patients predominantly had a rapidly rising value before death (figure). The median interval from increase in antigen concentration to death was only 5.5 months. No increase in antigen concentration occurred in the remaining five patients, two of whom were still alive.

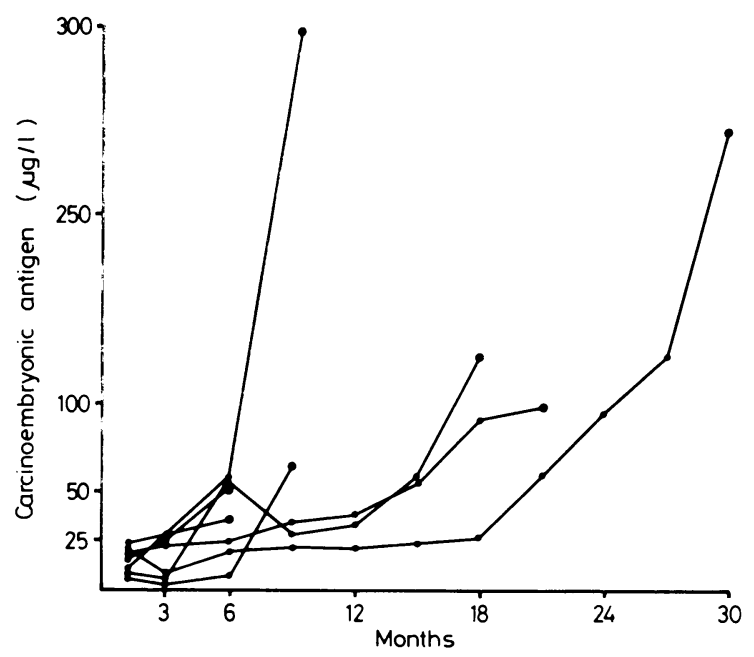

Pattern of increase in carcinoembryonic antigen values in seven patients with occult hepatic metastases. Final value in each case is last estimation before death.

\section{Discussion}

There has been much optimism that sequential estimation of the carcinoembryonic antigen concentration during the follow up of patients who have undergone curative resection for colorectal carcinoma might detect occult recurrent disease early enough for successful treatment. Grossly raised concentrations of the antigen occur in patients who have advanced hepatic, osseous, and pulmonary metastases. ${ }^{8}$ Most of these patients with advanced disseminated disease develop a rapid rise in values before death. ${ }^{9}$ Indeed, while there has been considerable debate about the role of the antigen in the detection of local recurrence, ${ }^{10} 11$ its value in the detection of disseminated disease has largely been accepted.12

We have reported the superiority of computed tomography over estimation of the carcinoembryonic antigen in the detection of occult hepatic metastases during the immediate postoperative period. ${ }^{6}$ The present study shows that the median time advantage gained by computed tomography over measuring the antigen was 7.5 months. In a similar prospective study Sugarbaker et al found a comparable mean interval from surgery to rise in antigen value of 7.8 months. ${ }^{13}$ In that study the subsequent mean interval from rise in value until clinical recognition of recurrent disease was only 3.4 months. Those workers concluded that the rise in carcinoembryonic antigen concentration occurred as a late phenomenon in the course of colorectal carcinoma. Our observation that the median interval between the rise in antigen concentration and death was only 5.5 months concurs with the observation of Sugarbaker $e t$ al.

In our study five out of 13 patients with hepatic metastases did not develop an increase in concentration of the antigen. Two of these patients were still alive, however, so that this figure may fall. Interestingly, MacKay et al observed no rise in carcinoembryonic antigen concentrations in seven of 31 patients with extensive hepatic metastases. ${ }^{14}$ Only two of our six patients with proved local recurrence alone developed a raised concentration. This observation was similar to that reported previously. ${ }^{10} 14$

Computed tomography is probably of limited value in the routine early detection of occult disseminated disease, since it is expensive, time consuming, and has an unacceptably high false positive rate. In our study however, used as a research tool, it allowed us to evaluate the role of carcinoembryonic antigen values in the detection of occult hepatic metastases.

These metastases were by definition not truly "occult," since they measured between 0.5 and $2.0 \mathrm{~cm}$ in diameter and had therefore been present for a considerable time. In an attempt to determine the development of hepatic metastases before detection by computed tomography rate of growth studies were undertaken. These entailed constructing growth curves based on sequential computed tomography of the metastases during the observed phase of growth. Mathematical extrapolation of these growth curves to an assumed one cell origin allows an estimation of duration of growth before detection by computed tomography. We have reported this to be a mean of three years. ${ }^{15}$ Since patients who have occult hepatic metastases as detected by computed tomography at the time of surgery have a mean survival of about two years, the overall life span of these metastases appears to be roughly five years. By these criteria serum concentrations of carcinoembryonic antigen become raised only late in the disease process.

We conclude that determination of the carcinoembryonic antigen concentration has not fulfilled its promise as a mode of early detection of disseminated disease, and it is unlikely that present modes of treatment instigated on the basis of a rise in concentration will confer benefit to the patient.

\section{References}

${ }^{1}$ National Institutes of Health. Consensus statement. Carcinoembryonic antigen: its role as a marker in the management of cancer. $\mathrm{Br} \mathrm{Med} \mathcal{F}$ 1981;282:373-5.

${ }^{2}$ Mach JP, Vienny H, Jaeger P, et al. Long term follow up of colorectal carcinoma patients by repeated CEA radioimmunoassay. Cancer 1978;42:1439-47.

${ }^{3}$ Martin EW, James KK, Hurtubise PE, et al. The use of CEA as an early indicator for gastrointestinal tumor recurrence and second look procedure. Cancer 1977;39:440-6.

4 Herrera M, Chu TM, Holyoke ED. Carcinoembryonic antigen (CEA) as a prognostic and monitoring test in clinically complete resection of colorectal carcinoma. Ann Surg 1976;183:5-9.

${ }^{5}$ Finlay IG, Meek D, Gray H, et al. Incidence and detection of occult hepatic metastases in colorectal carcinoma. Br Med f 1982;284:803-6.

${ }^{6}$ Finlay IG, McArdle CS. The identification of patients at high risk following curative resection for colorectal carcinoma. Brf Surg 1982;69:583-4.

${ }^{7}$ Lawrence DJR, Stevens U, Bettleheim R, et al. Role of plasma carcinoembryonic antigen in diagnosis of gastrointestinal, mammary, and bronchial carcinoma. Br Med $\mathcal{F} 1972$;iii :605-9.

${ }^{8}$ Wanebo HJ, Stearns M, Schwartz MK. The use of CEA as an indicator of early recurrence. Ann Surg 1978;188:481-93.

9 Wood CB, Ratcliffe JG, Burt RW. The clinical significance of the pattern of elevated serum carcinoembryonic antigen (CEA) levels in recurrent colorectal carcinoma. Br 7 Surg 1980;67:46-8.

${ }^{10}$ Moertel CG, Schutt AJ, Go VLW. Carcinoembryonic antigen test for recurrent colorectal carcinoma. Inadequacy for early detection. $\mathfrak{f} A M A$ $1978 ; 239$ :1065-6. 
Wedell J, Meier Zu Eissan J, Luu TH, et al. A retrospective study of serial CEA determinations in the early detection of recurrent colorectal cancer. Dis Colon Rectum 1981 ;24:618-21.

${ }_{12}$ Wanebo HJ. Are carcinoembryonic antigen levels of value in the curative management of colorectal cancer. Surgery $1981 ; 89: 290-5$.

13 Sugarbaker PH, Zamcheck N, Moore FD. Assessment of serial carcinoembryonic antigen (CEA) assays in postoperative detection of recurrent colorectal cancer. Cancer 1976;38:2310-5.
14 MacKay AM, Patel S, Carter S, et al. Role of serial plasma CEA assays in detection of recurrent and metastatic colorectal carcinoma. $\mathrm{Br}$ Med $\mathcal{f}<$ 1974 ;iv:382-5.

15 Finlay IG, Brunton F, Meek D. The rate of growth of hepatic metastases in colorectal carcinoma. Br $\mathcal{F}$ Surg 1982;69:689.

(Accepted 1 February 1983)

\section{SHORT REPORTS}

\section{Agranulocytosis associated with malaria prophylaxis with Maloprim}

Dapsone is an important drug in the treatment of leprosy and bullous dermatoses, particularly dermatitis herpetiformis, and has been used in prophylaxis against chloroquine resistant Plasmodium falciparum malaria, usually combined with pyrimethamine. Side effects include skin reactions and haematological disorders such as haemolytic anaemia and methaemoglobinaemia. ${ }^{1}$ Dapsone may also cause agranulocytosis during treatment and when used in malaria prophylaxis, ${ }^{23}$ where a mortality of $40 \%$ has been recorded. ${ }^{2}$ Pyrimethamine does not appear to have been associated with agranulocytosis.

We report seven cases of agranulocytosis, with three deaths, in persons taking Maloprim (dapsone $100 \mathrm{mg}$ and pyrimethamine 12.5 $\mathrm{mg}$ ) as prophylaxis against malaria in a dose of two tablets a week.

\section{Case reports}

Between January 1980 and December 1981 seven cases of agranulocytosis occurred in people taking Maloprim or within days of stopping the drug (see table). Two of the patients (cases 3 and 4) were brother and sister and al except one (case 5), who had suffered a transient cerebral ischaemic attack three years before and was taking salicylic acid daily, were otherwise wel and not taking any other drugs.

Full haematological data were not available in cases 2 and 3 , as these patients were admitted to hospital in Latin America and died four and three days after admission. Case records showed that one of these patients (case 3 ) had "agranulocytosis" and a bone marrow smear reported as showing "severe depression." In neither case were bacterial cultures carried out despite the patient in case 3 dying in "septic shock."

Three patients (cases 1,5 , and 7) were given adequate antibiotic treatment according to in vitro testing of isolated bacteria. Case 4 was treated with gentamicin and piperacillin intravenously. In cases 1,4 , and 7 the patients were also given buffycoat transfusions. The antimicrobial chemotherapy in the three patients who died (cases 2,3 , and 6) may not have been adequate, since blood cultures were not obtained and isoxazolylpenicillin but no aminoglycoside or modern broad spectrum penicillin or cephalosporin was $\vec{\circ}$ used.

\section{Comment}

Maloprim was the only factor that could be identified as causing the agranulocytosis in these seven patients. Their symptoms developed $\stackrel{\infty}{\circ}$ seven to nine weeks after beginning Maloprim, and the mortality 0 (three deaths) agrees with that reported for dapsone. ${ }^{2}$ We assume that the agranulocytosis was due to the dapsone in Maloprim, as a weekly dose of $175 \mathrm{mg}$ reportedly causes agranulocytosis, ${ }^{2}$ and all seven of $\overrightarrow{\mathrm{N}}$ these patients were taking $200 \mathrm{mg}$ a week. In vitro data show a dose $\vec{N}$ dependent toxic effect on the granulopoiesis promoted by hydrogen $\mathrm{O}$ peroxide and mediated by a metabolite of dapsone. ${ }^{5}$ The manufacturer's recommended dose of one tablet of Maloprim a week does not appear $\vec{\sigma}$ to have been associated with agranulocytosis; nevertheless, the low $D$ dose of pyrimethamine per tablet and the short half life of dapsone might suggest that two doses a week would be necessary for effective prophylaxis. ${ }^{4}$

The incidence of agranulocytosis due to dapsone given as prophylaxis against malaria has been estimated as one in $5000^{2}$; and according to the Swedish National Board of Health and Wellfare there were about 15000 prescriptions for Maloprim during the period that these patients became ill, yielding an incidence of about one in 2000 .

Thrombocytopenia was not a feature of the drug reaction reported 0 here. One case of thrombocytopenia associated with a twice weekly $\mathbb{Q}$ dose of Maloprim has, however, been reported to the Swedish $\vec{\overrightarrow{ }}$ Adverse Drug Reactions Advisory Committee.

Maloprim given in a dose of one tablet twice a week may cause agranulocytosis; the use of the lower dose of one tablet weekly or alternative drugs is advocated in persons travelling to areas in which chloroquine resistant $P$ falciparum malaria is endemic.

Clinical and pathological data in patients suffering from Maloprim associated agranulocytosis

\begin{tabular}{|c|c|c|c|c|c|c|c|c|c|}
\hline \multirow[b]{2}{*}{$\begin{array}{l}\text { Case } \\
\text { No }\end{array}$} & \multirow[b]{2}{*}{$\begin{array}{l}\text { Sex and } \\
\text { age }\end{array}$} & \multirow[b]{2}{*}{$\begin{array}{l}\text { Duration } \\
\text { of } \\
\text { Maloprim } \\
\text { treatment } \\
\text { (weeks) }\end{array}$} & \multirow[b]{2}{*}{$\begin{array}{l}\text { Presenting } \\
\text { symptoms }\end{array}$} & \multirow[b]{2}{*}{$\begin{array}{l}\text { Bacteriological } \\
\text { findings }\end{array}$} & \multicolumn{3}{|c|}{$\begin{array}{l}\text { Haematological picture } \\
\text { on presentation }\end{array}$} & \multirow[b]{2}{*}{ Bone marrow } & \multirow[b]{2}{*}{ Outcome } \\
\hline & & & & & $\begin{array}{c}\text { White cell } \\
\text { count } \\
\left(\times 10^{\circ} / 1\right) \\
(\% \\
\text { polymorphs })\end{array}$ & $\begin{array}{c}\text { Platelet } \\
\text { count } \\
\left(\times 10^{9} / 1\right)\end{array}$ & $\begin{array}{l}\text { Haemo- } \\
\text { globin } \\
(\mathrm{g} / \mathrm{l})\end{array}$ & & \\
\hline 1 & M 64 & 8 & $\begin{array}{l}\text { Fever and boil on } \\
\text { neck }\end{array}$ & $\begin{array}{l}\text { Staphylococcus aureus } \\
\text { in boil; blood } \\
\text { cultures sterile }\end{array}$ & $0 \cdot 1(2)$ & 68 & 120 & $\begin{array}{l}\text { Absence of granulocytes; } \\
\text { erythroid series and } \\
\text { megakaryocytes normal }\end{array}$ & $\begin{array}{l}\text { Recovered after } \\
3 \text { weeks }\end{array}$ \\
\hline 2 & F 27 & 8 & $\begin{array}{l}\text { Sore throat, earache, } \\
\text { and fever }\end{array}$ & $\begin{array}{l}\text { None } \\
\text { Nores sterile }\end{array}$ & $?$ & $?$ & $?$ & $\begin{array}{l}\text { Numerous myeloblasts, } \\
\text { arrest at promyelocyte } \\
\text { stage; erythroid series } \\
\text { and megakaryocytes } \\
\text { hyperactive }\end{array}$ & $\begin{array}{l}\text { Died } 4 \text { days } \\
\text { after admission } \\
\text { to hospital in } \\
\text { Latin America }\end{array}$ \\
\hline 3 & F 49 & 8 & Sore throat and fever & None & $?$ & $?$ & $?$ & "Severe depression" & $\begin{array}{l}\text { Died } 3 \text { days } \\
\text { after admission } \\
\text { to hospital in } \\
\text { Latin America }\end{array}$ \\
\hline 4 & M 47 & 8 & Sore throat and fever & Blood cultures sterile & $0.7(0)$ & 362 & 125 & $\begin{array}{l}\text { Absence of myelopoiesis; } \\
\text { erythroid series and } \\
\text { megakaryocytes normal }\end{array}$ & $\begin{array}{l}\text { Recovered after } \\
3 \text { weeks }\end{array}$ \\
\hline 5 & M 74 & 8 & $\begin{array}{l}\text { Fever, jaundice, and } \\
\text { lymphadenopathy }\end{array}$ & Coliforms in blood & $0 \cdot 2(0)$ & 165 & 104 & $\begin{array}{l}\text { Absence of myelopoiesis; } \\
\text { hypoplastic } \\
\text { erythropoiesis; }\end{array}$ & $\begin{array}{l}\text { Recovered after } \\
3 \text { weeks }\end{array}$ \\
\hline 6 & F 67 & 9 & Sore throat and fever & $\begin{array}{l}\text { Throat culture, } \\
\text { normal flora }\end{array}$ & $0.3(0)$ & 118 & 98 & $\begin{array}{l}\text { megakaryocytes normal } \\
\text { Absence of myelopoiesis; } \\
\text { hypoplastic } \\
\text { erythropoiesis; } \\
\text { megakaryocytes } \\
\text { increased }\end{array}$ & $\begin{array}{l}\text { Died after } 4 \\
\text { days in hospita }\end{array}$ \\
\hline 7 & F 32 & 7 & $\begin{array}{l}\text { Malaise, fever, and } \\
\text { pain in left } \\
\text { sternomastoid }\end{array}$ & $\begin{array}{l}\text { Staph aureus in } \\
\text { blood }\end{array}$ & $0 \cdot 3(0 \cdot 1)$ & 300 & 120 & $\begin{array}{l}\text { Absence of myelopoiesis; } \\
\text { erythroid series and } \\
\text { megakaryocytes normal }\end{array}$ & $\begin{array}{l}\text { Recovered after } \\
3 \text { weeks }\end{array}$ \\
\hline
\end{tabular}

